\title{
Pengembangan Video Animasi sebagai Media Layanan Informasi Sekolah Lanjutan bagi Siswa SMP
}

\author{
Elisa Adhistiya*, Muslihati, Lutfi Fauzan \\ Universitas Negeri Malang, Jl. Semarang No. 5 Malang, Jawa Timur, Indonesia \\ *Penulis korespondensi, Surel: elisa.adhis12@gmail.com
}

Paper received: 3-5-2021; revised: 24-5-2021; accepted: 28-5-2021

\begin{abstract}
This study aims to develop guidance and counseling information service media in the form of animated videos as secondary school information services for junior high school students. The research use model of Borg and Gall in 5 steps, namely (1) data collection, (2) planning, (3) designing the initial media format, (4) test validation, and (5) revision. The results of the acquisition of test validation of material experts show the validation by 1 , test validation of media experts show the validation of 0,875 , and validation and prospective users show the validation of 1 . It shows that the media developed by the researchers has been qualified acceptability and fit to be used as supporting media in giving guidance services in school.
\end{abstract}

Keywords: video animation; information the school of advanced; junior high school students

\begin{abstract}
Abstrak
Penelitian ini bertujuan untuk mengembangkan media layanan informasi bimbingan dan konseling berupa video animasi sebagai layanan informasi sekolah lanjutan bagi siswa SMP. Metode penelitian yang digunakan adalah model Borg and Gall dalam 5 tahap yaitu (1) pengumpulan data, (2) perencanaan, (3) merancang format media awal, (4) uji validasi, dan (5) revisi. Hasil perolehan dari uji validasi ahli materi menunjukkan indeks validasi sebesar 1, uji validasi ahli media menunjukkan indeks validasi sebesar 0,875 , dan uji validasi calon pengguna menunjukkan indeks validasi sebesar 1. Hal tersebut menunjukkan bahwa media yang dikembangkan oleh peneliti telah memenuhi syarat keberterimaan dan layak digunakan sebagai media penunjang dalam memberikan layanan bimbingan di sekolah.
\end{abstract}

Kata kunci: video animasi; informasi sekolah lanjutan; siswa SMP

\section{Pendahuluan}

Sekolah lanjutan siswa SMP merupakan jenjang pendidikan selanjutnya yaitu jenjang pendidikan menengah sebagai lanjutan dari SMP/MTs atau bentuk lain yang sederajat atau lanjutan dari hasil belajar yang diakui sama atau setara SMP/MTs. Sekolah lanjutan siswa SMP diantaranya adalah Sekolah Menengah Atas (SMA), Sekolah Menengah Kejuruan (SMK), dan Madrasah Aliyah (MA). Salah satu permasalahan yang seringkali dialami oleh siswa SMP adalah kebingungan dengan pilihan dalam menentukan sekolah lanjutan. Kurangnya pemahaman informasi mengenai sekolah lanjutan itulah yang menjadi hambatan. Sebenarnya dalam memilih sekolah lanjutan tidaklah sulit, apabila siswa telah mendapatkan pengarahan dan pemahaman yang tepat.

Setiap siswa menginginkan suatu karier yang cemerlang, dan karier tersebut diwujudkan dengan suatu usaha dan direncanakan secara matang (Pambudi, 2019). Perencanaan karier di SMP sangat dibutuhkan, hal ini selaras dengan tugas perkembangan karier siswa SMP, yakni mengenal bakat minat, serta arahan kecenderungan karier, mengembangkan pengetahuan dan keterampilan untuk mengikuti dan melanjutkan pelajaran 
atau persiapan karier serta berperan dalam kehidupan masyarakat terkait dengan tugas perkembangan persiapan diri dalam meniti karier, siswa yang telah menyelesaikan pendidikan di Sekolah Menengah Pertama (SMP) hendaknya tidak langsung berpuas diri, akan tetapi melanjutkan ke jenjang pendidikan yang lebih tinggi, yakni pada jenjang setingkat Sekolah Lanjutan Tingkat Atas (SLTA).

Layanan informasi merupakan upaya membantu siswa menerima dan memahami berbagai informasi diri, sosial, belajar, karier, dan pendidikan lanjutan (Hamdani, 2012). Melalui layanan informasi yang diberikan oleh konselor, siswa dapat menerima dan memahami berbagai informasi yang dapat digunakan sebagai pengambilan keputusan untuk kepentingan siswa itu sendiri. Dengan demikian, kebutuhan akan informasi sangat diperlukan siswa, termasuk kebutuhan informasi karier.

Bimbingan dan konseling di sekolah memiliki tugas yang penting dalam membantu siswa seperti pengembangan potensi diri dan persiapan dalam berkarier. Bentuk bantuan yang dapat diberikan oleh konselor dalam kaitannya dengan karier mencakup konseling karier, bimbingan kelompok mengenai karier hingga pemberian informasi karier. Salah satu layanan dalam bimbingan karier yang dapat dilakukan oleh konselor yakni layanan informasi karier.

Dalam pelaksanaan pemberian layanan informasi, tidak semua informasi karier yang dibutuhkan siswa dapat terlayani oleh konselor di sekolah. Maka dari itu, layanan informasi membutuhkan media yang tepat agar siswa dapat menerima dan memahami dengan baik informasi yang disampaikan. Media dapat digunakan untuk menyampaikan pesan dalam proses pembelajaran sehingga meningkatkan antusias siswa untuk belajar.

Peneliti bermaksud mengembangkan video animasi sebagai media layanan informasi sekolah lanjutan bagi siswa SMP. Selain itu, peneliti juga mengembangkan buku panduan cara menggunakan media video animasi tersebut. dengan adanya media ini, dapat meningkatkan pemahaman siswa mengenai sekolah lanjutan.

\section{Metode}

Metode penelitian pengembangan yang digunakan dalam penelitian ini adalah model Borg and Gall yang terdiri dari 10 tahap (1983), yaitu : (1) penelitian dan pengumpulan informasi awal, (2) perencanaan, (3) pengembangan produk awal, (4) uji coba produk, (5) revisi produk, (6) uji coba lapangan, (7) revisi produk, (8) uji lapangan, (9) revisi produk akhir, (10) destinasi dan implementasi.

Pada penelitian ini, prosedur penelitian model Borg and Gall tersebut disesuaikan dengan kebutuhan peneliti. Prosedur penelitian yang dilakukan peneliti adalah (1) pengumpulan data meliputi (a) menyebarkan angket need assessment untuk mengetahui kebutuhan siswa, (b) melakukan kajian literature dengan mengkaji teori-teori yang relevan serta penelitian-penelitian terkait yang telah dilakukan, (2) langkah-langkah perencanaan yaitu (a) menentukan tujuan penelitian, (b) menyusun instrumen need assessment siswa, (c) mendesain media video animasi, (d) menyusun buku panduan, dan (e) menyusun instrumen uji ahli, (3) melakukan penelitian dan pengembangan sampai pada tahap kelima yaitu revisi setelah menilai produk pada uji ahli, video akan dikemas dengan animasi, teks dan dubbing di dalamnya untuk memperjelas pesan yang akan disampaikan, (4) uji coba produk dilakukan oleh dua ahli materi yaitu dosen Bimbingan dan Konseling, dua ahli media yaitu dosen Bimbingan dan Konseling serta dosen Teknologi Pendidikan, dan dua calon pengguna yaitu 
konselor SMP Negeri 1 Kalitidu, (5) revisi dilakukan setelah mendapatkan penilaian dan catatan dari para ahli.

Teknik analisis data pada penelitian pengembangan ini adalah data kuantitatif dan kualitatif. Teknik analisis kualitatif berupa masukan, saran, dan tanggapan dari ahli materi bimbingan dan konseling, ahli media, dan calon pengguna. Data kualitatif diuraikan dengan jelas sehingga dapat digunakan sebagai dasar untuk menyempurnakan produk yang dikembangkan. Sedangkan teknik analisis kuantitatif digunakan untuk memperoleh data dari uji ahli materi bimbingan dan konseling, uji ahli media, dan uji calon pengguna (konselor) dianalisis untuk mencari validitas produk. Adapun aspek dalam instrumen penilaian yaitu ketepatan, kemudahan, kegunaan, dan kemenarikan. Rumus yang dipakai adalah:

\begin{tabular}{|c|c|c|c|}
\hline & & PENDAPA & \\
\hline & & $\begin{array}{c}\text { Relevansi Rendah } \\
\text { (1-2) }\end{array}$ & $\begin{array}{c}\text { Relevansi Tinggi } \\
(3-4)\end{array}$ \\
\hline PENDAPAT & $\begin{array}{l}\text { Relevansi } \\
\text { Rendah } \\
(1-2)\end{array}$ & A & B \\
\hline & $\begin{array}{l}\text { Relevansi } \\
\text { Tinggi } \\
(3-4)\end{array}$ & $\mathrm{C}$ & D \\
\hline
\end{tabular}

\section{Gambar 1. Inter-raterAgreement Model}

Berdasarkan model kesepakatan (inter-rater agreement model) di atas, peneliti menentukan indeks hasil uji calon pengguna produk dengn menggunakan rumus berikut.

Indeks Uji Ahli $=\frac{D}{A+B+C+D}$

Keterangan:

A: Relevansi rendah dari pengguna 1 dan 2

B: Relevansi tinggi dari pengguna 1 dan relevansi rendah dari pengguna 2

C: Relevansi tinggi dari pengguna 2 dan relevansi rendah dari pengguna 1

D: Relevansi tinggi dari pengguna 1 dan 2

Kategori indeks uji validitas mengacu pada pengklasifikasian validitas yang diadaptasi dari Akbar dan Sriwijaya (2010).

Tabel 1. Kriteria Validitas Analisis Persentase

\begin{tabular}{clc}
\hline Indeks Uji Ahli & \multicolumn{1}{c}{ Klasifikasi Validitas } & Keterangan \\
\hline $0,76-1,00$ & $\begin{array}{l}\text { Sangat tepat, sangat bermanfaat, } \\
\text { sangat menarik, sangat praktis } \\
\text { Cukup tepat, cukup bermanfaat, } \\
\text { cukup menarik, cukup praktis } \\
\text { Kurang tepat, kurang bermanfaat, } \\
\text { kurang menarik, kurang praktis } \\
\text { Tidak tepat, tidak bermanfaat, tidak } \\
\text { menarik, tidak praktis }\end{array}$ & Perlu revisi \\
$0,26-0,50$ & Perlu revisi \\
$0,00-0,25$ & Revisi total \\
\hline
\end{tabular}




\section{Hasil dan Pembahasan}

\subsection{Hasil}

Produk pertama dalam penelitian dan pengembangan ini adalah video animasi. Video animasi yang dikembangkan berisikan beberapa materi. Materi yang disajikan adalah pemberian layanan informasi melalui media video animasi, macam-macam sekolah lanjutan setelah SMP, ketersediaan jurusan dan prospek jurusan pada jenjang sekolah lanjutan tingkat atas (SLTA).

Media video animasi memberikan tampilan warna pastel sehingga terkesan soft dan tidak mencolok. Jenis font yang dipilih sangat mudah dibaca. Ditambahkan dubbing sebagai penjelas materi yang ditampilkan dalam video.

Produk kedua adalah buku panduan. Buku panduan disusun sebagai pedoman konselor dalam menggunakan media video animasi. Terdapat beberapa bagian dalam buku panduan ini. Bagian pertama pendahuluan berisikan rasional, tujuan, sasaran bimbingan, dan sumber bacaan. Bagian kedua berisikan deskripsi produk dan petunjuk penggunaan akses video animasi. Bagian ketiga dalam buku panduan ini berisikan RPLBK (Rencana Pelaksanaan Layanan Bimbingan dan Konseling) yang membantu konselor dalam memberikan layanan bimbingan dan konseling.

Buku panduan didesain dengan menggunakan warna pastel. Warna pastel dipilih karena memberikan dukungan munculnya rasa positif dari diri seseorang. Selain itu juga ditambahkan gambar yang sesuai dengan judul buku panduan yaitu video animasi sebagai media layanan informasi sekolah lanjutan bagi siswa SMP. Gambar yang dipilih adalah adanya siswa dengan latar background sekolah.

Produk tersebut kemudian diujikan kepada ahli materi bimbingan dan konseling, ahli media dan calon pengguna untuk mengetahui kualitasnya. Hasil penilaian produk video animasi sebagai media layanan informasi sekolah lanjutan dinilai oleh dua ahli materi bimbingan dan konseling. Hasil penilaian dari dua ahli materi bimbingan dan konseling menyatakan bahwa produk video animasi sebagai media layanan informasi sekolah lanjutan menunjukkan indeks validasi sebesar 1 dan termasuk dalam kategori sangat tinggi. Hal tersebut sesuai dengan klasifikasi dari Akbar \& Sriwijaya (2010) yang menyatakan bahwa indeks validasi ahli sebesar 0,76 sampai dengan 1,00 termasuk dalam klasifikasi validitas sangat tepat, sangat bermanfaat, sangat menarik, dan sangat praktis.

Hasil penilaian produk video animasi sebagai media layanan informasi sekolah lanjutan dinilai oleh dua ahli media. Hasil penilaian dari dua ahli media menyatakan bahwa produk video animasi sebagai media layanan informasi sekolah lanjutan menunjukkan indeks validasi sebesar 0,875 dan termasuk dalam kategori sangat tinggi, sehingga produk termasuk dalam klasifikasi validitas sangat tepat, sangat bermanfaat, sangat menarik, dan sangat praktis.

Produk video animasi yang telah direvisi dilakukan uji calon pengguna yaitu kepada dua orang konselor sekolah. Hasil penilaian produk video animasi sebagai media layanan informasi sekolah lanjutan menunjukkan indeks validasi sebesar 1, maka termasuk dalam klasifikasi validitas rentang nilai 0,76 sampai dengan 1,00 sehingga produk dinilai memiliki validitas yang sangat tinggi (sangat tepat, sangat bermanfaat, sangat menarik, sangat praktis). 


\subsection{Pembahasan}

Produk yang dikembangkan peneliti memperoleh indeks validasi dari ahli materi bimbingan dan konseling sebesar 1 dan termasuk dalam kategori sangat tinggi. Produk ini sangat tepat karena dirancang berdasarkan hasil need assessment. Need assessment merupakan hal yang dilakukan pertama dalam mengembangkan program bimbingan dan konseling. Need assessment dilakukan untuk mendapatkan informasi-informasi yang akurat mengenai kebutuhan program bimbingan dan konseling (Flurentin, 2016). Berdasarkan need assessment tersebut peneliti mengetahui secara pasti kebutuhan siswa terkait produk peneliti.

Produk yang dikembangkan peneliti memperoleh indeks validasi dari ahli media sebesar 0,875 dan termasuk dalam kategori sangat tinggi, sehingga produk termasuk dalam klasifikasi validitas sangat tepat, sangat bermanfaat, sangat menarik, dan sangat praktis. Hasil ini berarti produk yang dikembangkan peneliti sangat berguna. Produk ini sangat berguna untuk konselor untuk memberikan informasi sekolah lanjutan. Hal ini dikarenakan produk peneliti digunakan untuk memberikan layanan informasi sekolah lanjutan bagi siswa SMP.

Produk yang dikembangkan peneliti memperoleh indeks validasi dari calon pengguna sebesar 1, maka termasuk dalam klasifikasi validitas rentang nilai 0,76 sampai dengan 1,00 sehingga produk dinilai memiliki validitas yang sangat tinggi (sangat tepat, sangat bermanfaat, sangat menarik, sangat praktis).

Berdasarkan uraian di atas maka produk video animasi sebagai media layanan informasi sekolah lanjutan dan buku panduannya telah memenuhi syarat keberterimaan. Produk dapat digunakan oleh konselor di sekolah untuk memberikan layanan bimbingan dan konseling dalam bidang karier, dengan adanya media bimbingan dapat meningkatkan optimalisasi pelayanan bimbingan dan konseling.

\section{Simpulan}

Berdasarkan pembahasan sebelumnya dapat disimpulkan bahwa produk animasi sebagai media layanan informasi sekolah lanjutan telah memenuhi syarat keberterimaan dan layak digunakan sebagai media penunjang layanan bimbingan karier khususnya dalam memberikan layanan informasi sekolah lanjutan untuk siswa SMP.

\section{Daftar Rujukan}

Akbar, S., \& Sriwijaya, H. (2010). Pengembangan Kurikulum dan Pembelajaran Ilmu Pengetahuan Sosial. Yogyakarta: Cipta Media.

Borg, W.R \& Gall, M.D. (1983). Educational Research And Introduction. New York: Longman Inc.

Flurentin, E. (2016). Manajemen Bimbingan dan Konseling. Malang: Universitas Negeri Malang

Gregory. R. J. \& Jack G. W. (2011). Marketing Corporate Image: The Company as Your Number One Product. New York: McGraw Hill.

Hamdani. (2012). Bimbingan dan Penyuluhan. Bandung: CV Pustaka Setia.

Pambudi, P. R., Muslihati, M., \& Lasan, B. B. (2019). Strategi untuk Membantu Meningkatkan Perencanaan Karier Siswa di Era Revolusi Industri 4.0. Jurnal Konseling Indonesia, 5(1), 28-33. 